Vol. 9, n² | 2005

Varia

\title{
The Abolition of the Burning of Women in England Reconsidered
}

Simon Devereaux

\section{(2) OpenEdition \\ Journals}

Electronic version

URL: https://journals.openedition.org/chs/293

DOI: $10.4000 /$ chs. 293

ISSN: 1663-4837

Publisher

Librairie Droz

Printed version

Date of publication: 1 December 2005

Number of pages: $73-98$

ISBN: 978-2-600-01054-2

ISSN: $1422-0857$

\section{Electronic reference}

Simon Devereaux, "The Abolition of the Burning of Women in England Reconsidered", Crime, Histoire \& Sociétés / Crime, History \& Societies [Online], Vol. 9, n² | 2005, Online since 26 February 2009,

connection on 22 March 2022. URL: http://journals.openedition.org/chs/293 ; DOI: https://doi.org/ $10.4000 /$ chs. 293

This text was automatically generated on 22 March 2022.

(c) Droz 


\title{
The Abolition of the Burning of Women in England Reconsidered ${ }^{1}$
}

\author{
Simon Devereaux
}

1 Soon after seven o'clock on the morning of Wednesday, 25 June 1788, a scene familiar to many Londoners was enacted outside Newgate Prison in the Old Bailey. Three men, one convicted of burglary and the other two of coining, were brought out the Debtors' Door of the prison onto a temporary platform erected for the occasion. Newspaper accounts of what followed passed over in silence (as most at this time usually did) the full details of the next three-quarters of an hour, during which time these men presumably received what spiritual comfort could be afforded them by prayer as the nooses were placed about their necks and their feet positioned above the trapdoor of the scaffold. They were dead before 8 a.m., and if the usual form in such cases was followed on this occasion, their bodies would have been cut down within an hour and the gallows on which they died cleared away soon afterwards ${ }^{2}$.

2 Such execution scenes were not unusual in late eighteenth-century London. England's «bloody code», after all, prescribed the death sentence for more than two hundred distinctly-defined criminal offenses, and it would still be nearly half a century before the law would decisively abandon its insistence upon maintaining the option of executing people convicted of crimes other than murder ${ }^{3}$. In fact, the three men hanged this day constituted a display of relative restraint on the part of officialdom by comparison with the groups of ten- to fifteen-odd convicts at a time who had been executed on individual Newgate hanging days during the $1780 \mathrm{~s}^{4}$. Indeed the case could be made that the abolition only five years earlier of the Tyburn execution ritual, distinguished in the eyes of many principally for the rowdy disorder it provoked in its otherwise unmoved spectators, signalled the beginnings of a more civilized approach to the way in which the law's ultimate sanction was applied in the nation's capital ${ }^{5}$. Followers of Michel Foucault - who detect a darker exercise of "power» in the enlightenment-era transition from punishments publicly imposed on the criminal's body to those directed at his or her mind and scrupulously hidden away behind prison walls - might see in this adoption of a more rapid and effective execution ritual outside 
Newgate a particular attempt to inflict more secretive torments on the minds of its inmates ${ }^{6}$.

3 Whatever view one takes of that matter, however, what followed on the particular morning in question seemed to many contemporaries to defy any claims to enlightenment that the English criminal law might entertain. «After the men had been hanging about a quarter of an hour», London's leading daily newspaper reported, a woman named Margaret Sullivan «was brought out, dressed in black, attended by a priest of the Romish persuasion. As soon as she came to the stake she was placed upon the stool, which after some time was taken from under her [and she strangled to death], when the faggots were placed round her, and being set fire to, she was consumed to ashes» ${ }^{7}$. Nor was this the end of the display. Sixty years later, one man recalled happening upon the scene. «Passing in a hackney-coach up the Old Bailey to West Smithfield», he wrote, «I saw the unquenched embers of a fire opposite Newgate; on my alighting I asked the coachman 'What was the fire in the Old Bailey, over which the wheel of your coach passed?' 'Oh, sir,' he replied, 'they have been burning a woman for murdering her husband.'» In the latter particular at least, this aged Victorian witness was in error. Yet it is hard even now, in our post-enlightenment, postHolocaust age, not to shudder at the idea that the man's carriage may actually have passed through Margaret Sullivan's still-flickering remains. «It is, perhaps, as well to state», he added, «that there were some fifteen to twenty persons standing around the smouldering embers at the time I passed $»^{8}$.

4 This act and its display triggered a furore in London's papers. «Must not mankind laugh at our long speeches against African slavery - and our fine sentiments on Indian cruelties», observed the London Times, "when just in the very eye of the Sovereign we roast a female fellow creature alive, for putting a pennyworth of quicksilver on a half-penny worth of brass. The savage barbarity of the punishment - and the smallness of the offence in the eye of God are contrasts that should merit the consideration of Government»'. The Gentleman's Magazine addressed its objections directly to the prime minister himself, William Pitt, who being «himself a lawyer, 'tis hoped, will not suffer this cruel remain of savage legislation to escape his notice, and continue a disgrace to the enlightened sense of this country ${ }^{10}$. The permanent abolition of such executions took place, with little fanfare, only two years later (by the $30 \mathrm{Geo}$. III, c.48), and although many historians have addressed the end of this most spectacular survival of more ancient penal practices, most have largely concurred with the contemporaries quoted here in seeing it as a long-overdue measure in an age characterized by the growth of reason, sentiment and humanity ${ }^{11}$.

5 This article argues that, while it is undoubtedly the case that self-consciously enlightened attitudes towards punishment, as well as increasingly idealized conceptions of womanhood, established the context for the abolition of the burning of women in England, these socio-cultural developments were decisively abetted by practical circumstances and principally advocated by a group of men - the sheriffs of London and Middlesex - whose appearance in the vanguard of reform may come as a surprise. The first part of this paper reviews the evidence that may be invoked to argue for the role of changing social and cultural imperatives, suggesting some of the difficulties (and even contradictions) that emerge from a closer reading of the evidence. The second section argues the centrality of hitherto neglected features of the story: the particular objections of the sheriffs charged with enforcing the criminal law; 
the unexpected frequency with which the burning of women was enforced in London during the 1780s; and the unanticipated consequences for this particular mode of execution in light of the 1783 decision to abolish the Tyburn hanging procession. In arguing as I do, I seek to follow V.A.C. Gatrell's recent advice that historians should view the causes of penal and legal reform as «multiple, and [that] only rash historians would privilege material, or political, or cultural causes without interrelating all three» $»^{12}$.

6 There is a broad consensus amongst historians of English and European penal practices that major changes were underway from the late eighteenth century onwards ${ }^{13}$. Whatever value historians might now choose to place upon the different dimensions of «enlightened» attitudes towards punishment, there is an essentially sound case for viewing the abolition of the burning of women as a product of their increasingly rapid growth and diffusion from about 1770 onwards. Until 1790, burning at the stake was prescribed for all women convicted of treason of two varieties. The first, «high treason", in addition to its overt political definitions, could take the form of counterfeiting the gold or silver coin of the realm. (Counterfeiting coin made from copper or other base metals, by comparison, was only a regular capital felony $)^{14}$. The second, "petty treason», was defined in 1350 as consisting of three other acts of rebellion against major, non-royal authorities: a wife's murder of her husband; a servant's murder of his or her master or mistress; and a clergyman's murder of his religious superior ${ }^{15}$. When it came to punishing all these crimes, a critical distinction was observed between the sexes. «The judgment against a woman for high treason is not the same as against a man traitor», observed one legal authority as late as 1777 , that is

to be hanged, cut down alive, have the bowels taken out, and the body quartered; but she is to be drawn to the place of execution, and there burnt. For the public exhibition of [women's] bodies, and dismembering them, in the same manner as is practised to the men, would be a violation of that natural decency and delicacy inherent, and at all times to be cherished in the sex. And the humanity of the English nation has authorized by a tacit consent, an almost general mitigation of such part of their judgments, as savours of torture and cruelty; a sledge or hurdle being allowed to such traitors as are condemned to be drawn; and there being very few instances (and those accidental and by negligence) of any person being embowelled or burnt, till previously deprived of sensation by strangling ${ }^{16}$.

7 We are faced at the outset, then, with something of a paradox. For while we might easily share one recent historian's conviction that the reform of 1790 came about because «the tensions between the pain customarily delivered upon the criminal woman and the chivalric ideal seem to have reached breaking-point», the issue seems not to have been so clear-cut amongst many contemporaries who regarded the actual practice of burning women already to be a sufficiently chivalrous concession to female delicacy ${ }^{17}$. The same position had been endorsed by no less an authority than William Blackstone, the preeminent jurist of his era, as well as a leading advocate of such other penal reforms as the more restricted use of England's infamous «bloody code» and the wider adoption of imprisonment in place of execution or transportation ${ }^{18} \cdot$ «[I]n treasons of every kind», Blackstone famously remarked in 1769, «the punishment of women is the same, and different from that of men. For, as the decency due to the sex forbids the 
exposing and publicly mangling their bodies, their sentence (which is to the full as terrible to sensation as the other) is to be drawn to the gallows, and there to be burned alive» ${ }^{19}$.

Were it not for the explicit (if admittedly odd-looking) chivalry of such sentiments, one would have no hesitation in reading the protests of the 1780 s and repeal of 1790 as an unproblematic manifestation of changing social and cultural ideas regarding gender norms. After all, Leonore Davidoff and Catherine Hall have traced the origins of the domestic ideology of Victorian England - one in which women were viewed as morally idealized but passive figures, to be worshipped as Angels of the House, and certainly not brutalized in public - to the late eighteenth-century writings and activism of evangelicals, especially the Clapham Sect ${ }^{20}$. The leading role of William Wilberforce in sponsoring a first, failed bill to abolish the burning of women in 1786 might seem particularly telling in this regard ${ }^{21}$. In a similar vein, G.J. Barker-Benfield has linked the rise of a «culture of sensibility» in mid- to late eighteenth-century England with the development of a self-consciously «feminine» turn of $\operatorname{mind}^{22}$. That more recent historians have detected a more complex chronology of change and conceptual frameworks surrounding gender ideologies, insisting upon both an earlier development of the domestic ideal as well as a more thoroughly contested role for women in the public as well as the private spheres, may even be beside the point ${ }^{23}$. Blackstone and many others already believed the claims of female decency and delicacy to be answered.

9 Certainly this was the view of Lord Chief Justice Loughborough (again, like Blackstone, a sympathizer with restraint and reform of the «bloody code» in many other respects) in rejecting Wilberforce's 1786 measure ${ }^{24}$. The provision had been quickly attached to another bill in the wake of the burning of Phoebe Harris outside Newgate in June 1786 and the outrage that event had provoked in the public press (on which more momentarily). Loughborough, however, maintained that «he saw no great necessity for the alteration", partly

because although the punishment, as spectacle, was rather attended with circumstances of horror, likely to make a more strong impression on the beholders than mere hanging, the effect [on the culprit] was much the same, as in fact, no greater degree of personal pain was sustained, the criminal always being strangled before the flames were suffered to approach the body ${ }^{25}$.

This might look like so much hairsplitting to modern readers, so it is important to note here that, in fact, an extraordinarily large number of the expressions of protest registered in contemporary newspapers wrongly expressed a conviction that the women in question had been burned alive. This seems even more to have been the case with the execution of Margaret Sullivan in 1788 than that of Phoebe Harris two years earlier ${ }^{26}$. The idea that a woman could be burned alive, especially prevalent in the reportage of The Times, perhaps gave credence to that paper's resort to images of «torture» and «barbarism», whilst simultaneously holding forth the superior examples of «savages» in other parts of the world. The indignation of The Times in the days following Sullivan's execution seemed to know no rhetorical bounds. «Is the burning a woman no torture? The very savages in the wildest parts of the world, pay respect to their females, while Great Britain selects their tender bodies as the only objects for excruciating torture» (25 June 1788). More humiliating still for the thoughtful Englishman, it thundered, should be the more merciful practice of those «savages» 
closest to home, his own Irish subjects. «Rude and unpolished as the Irish were», they at least strangled the woman first and then

some faggots being placed round her, they are set on fire; but before the blaze touches the body, the friends convey it into a coffin, and publicly take it away, the upper garments are given to the mob and thrown into the fire. Must the elder sister blush for the superior humanity of the younger on these occasions, and direct her to have a public feeling for the most beautiful and tender part of the creation, which she at present practices not? (30 June 1788) ${ }^{27}$.

Clearly much of this indignant rhetoric can be read as being rooted in the growing reverence for domesticated womanhood that we might expect to see at this time.

On the other hand, it is not always clear that the particular ideal of femininity being upheld in these outcries was necessarily new: that they stemmed from that particularly powerful idealization of the female body that is so inseparably associated with Victorian gender ideologies. In yet another passage, The Times thundered against «the torturing barbarity on the body of [an] unhappy female... Shame on [the law], thus to attack the female sex, who by being the weaker body, are more liable to error, and less entitled to severity» (27 June 1788). The notion of the female «body» as being morally weaker and more prone to sin is one of the oldest images in western gender ideologies, one with roots extending far back to the origins of Judao-Christian culture ${ }^{28}$. Why should it have carried more weight as a rationale for mitigating the letter of the law for women during the late eighteenth century than at any time previously? How much less might it have carried if it had been more widely understood that the women were not in fact burned alive?

In any case, what appears to have aroused almost as many objections was the more simple fact that men who had been similarly convicted of treasonous coining had long since ceased to be subjected to the full physical agonies and indignities prescribed by law, and for which strangling and burning were supposedly a «merciful» alternative. Thus, while Isabella Condon was drawn to Tyburn on a sledge and burnt at the stake in October 1779 for coining, her husband Thomas, when convicted on a similar charge only three years later, was also dragged there on a sledge but only hanged ${ }^{29}$. And with the abolition of the traditional procession of the condemned to Tyburn after November 1783, male coiners could no longer be subjected even to the indignity of being drawn on a sledge to the site of execution. The issue for some, then, was not so much (or even) the indignity imposed on the female form, but rather the manifest gender inequality in the character of the punishment for the same crime. Thus, six months after Isabella Condon's execution, one debating club proposed the resolution, «Is there not cruelty in the law, that punished a woman with burning, for the same crime which a man is only hanged for? $\aleph^{30}$ The Times (and other papers) took up the theme after Phoebe Harris's execution in June 1786:

The execution of a woman for coining on Wednesday morning, reflects a scandal upon the law... and was not only inhuman, but shamefully indelicate and shocking. Why should the law in this species of offence inflict a severer punishment upon a woman, than a man. It is not an offence which she can perpetrate alone - in every such case the insistence of a man has been found the operating motive upon the woman; yet the man is but hanged, and the woman burned ${ }^{31}$.

For some critical observers, it need not have been so much that women in particular should not be treated so horribly as men, rather only that they should be treated no more so. 
13 Whatever its substantive basis, the concentrated outrage that greeted the executions of Harris and Sullivan seems to have had an impact on officials. The horror expressed on the former occasion perhaps inspired the judges to read the law so as to enable Henrietta Radbourne, convicted of murdering her mistress the year after, to be hanged for murder rather than burned for petty treason ${ }^{32}$. Another London woman convicted of coining in April 1788, Catherine Heyland, was to be executed barely a month after Sullivan, but her punishment was ultimately commuted to transportation for life. Evidence produced after the trial had suggested that Heyland was in fact guilty only of uttering false coin (for which the relevant law sanctioned benefit of clergy - that is, a relatively straightforward pardon - on a first conviction) rather than the coining itself. But it is surely significant that, in recommending to the king that mercy be shown her, the Home Secretary also emphasized «the disgust and horror which was lately occasioned by the burning a woman for the crime of coining» (i.e., Sullivan) ${ }^{33}$.

On the other hand - and here we come to the heart of the matter - the strangling and burning of Christian Murphy for coining in March 1789 was greeted with deafening silence on the part of London newspapers ${ }^{34}$. Nor did the approaching (and finally averted) execution of Sophia Girton the year after - whose impending fate presumably gave impetus to the abolition of the punishment only a few months later - provoke any comment in the periodical press ${ }^{35}$. In light of the intensity of earlier responses, this might seem largely irrelevant. Yet surely it is odd that, if public outrage was the major explanatory factor at work, there should be so little explicit comment on the matter to be found in a periodical press that had been so fulsome on the issue only a year or two earlier. If mounting public indignation were really the driving force of abolition the year after, why were there no parallel howls of execration on these latter, seemingly definitive occasions? Why were no legislative efforts made to abolish the practice following the executions of 1787 and 1788 , as there had been in 1789 ? $^{36}$

Part of the answer may be found in the nature of late eighteenth-century newspapers and their consequent limitations as a means of gauging «public opinion».. The daily newspapers of the era were only four pages long, of which nearly half was given over to advertisements. Of the remaining two to two-and-a-half pages allotted to news coverage proper, reportage of the parliamentary debates received pride of place. Consequently, during those nine to ten months of the year that parliament was in session, the space newspapers gave to any other news, much less editorial commentary, was often extremely limited, and thus the extent to which any newspaper might function as a direct means of measuring non-parliamentary sentiments on social issues of the day is markedly limited. In May and June of 1790, for instance, the months during which the burning of women was at last abolished by parliament, the space left over after parliamentary debates was almost entirely filled by accounts of the proceedings of the National Assembly of revolutionary France, the trial of Warren Hastings in the House of Lords, and reports of the escalating tensions between Britain and Spain over Nootka Sound. The picture is made more complicated still by the fact that many papers stole text wholesale from another ${ }^{37}$. Such repetition certainly suggests a shared opinion, but it also tends to obscure finer considerations as to how deeply-held or closely-considered that opinion might have been by the poaching newspaper. Most of the quotations deployed in this article have been taken from The Times, and this is no coincidence, for the leading daily newspaper of the era - the 
Morning Chronicle - was virtually silent on the issue, while The Times appears to have been the source of text for many other papers of the day ${ }^{38}$.

Finally, it should also be noted that other, more popularly-oriented publications suggest the persistence of wholly non-problematic views of the punishment of burning ${ }^{39}$.The executions of Harris and Christian Murphy, as well as the impending but ultimately averted execution of Catherine Heyland, gave rise to broadsheet and chapbook publications, all of which suggest a casual acceptance of the fates of the women and the larger moral message underlying their public immolation. Readers in 1786 were offered The Groans of Newgate, Sorrowful Lamentation, and Last Farewell to the World.of Phoebe Harris for their edification. «Poor wretched soul», its dolerous verse intoned:

... how must her heart

With trembling seat sore ake,

To think that soon she must be burnt

To ashes at the stake.

Clearly, though, Harris merited her fiery fate («A dreadful death to die») for succumbing to the ultimate feminine vice:

I did take delight in pride,

My beauty I thought great,

O then full little did I think,

of coming to this fate;

Pride and pomp are gone and fled,

Wednesday is the day,

When at the stake, consuming fire,

of me will make a prey.

...

Jesus have mercy on my soul,

In pity to me turn,

Farewell, vain world, my race is run,

I in the fire must burn ${ }^{40}$.

The author of The True and Remarkable Li[fe] and Adventures of Catherine Heyland, condemned to be burnt at the stake for Coining (who must have been a little disappointed by her ultimate escape) appears to have felt more sympathy for his subject («a decent looking woman, in her person rather plain»), though he or she chose to portray Heyland ultimately as a willing, if terrified sacrifice to a justice which was ultimately imitative of God's greater judgment and mercy:

I Catherine Heyland, doom'd to death,

Must in the flames resign my breath,

O Lord receive my soul on high,

When to the stake I'm brought to die.

...

O Lord, my soul with fright doth shrink,

I dread this cup which I must drink,

O Jesus Christ I pray look down,

Prepare me for a heavenly crown ${ }^{41}$.

17 And the composer of The Life and Death of Christian Bowman, alias Murphy seemed similarly sympathetic to the extent to which his or her subject had apparently fallen under the pernicious influence of a wicked man, as well as Murphy's last spiritual and physical agonies:

... Virtue, young females, ne'er forsake.

The laws of your country do not break. 
...

Some thousands of persons did appear,

As to the stake she then drew near,

Think, think, how shocking was her fate,

By flames consumed in the street ${ }^{42}$.

The contrast of such sentiments as expressed in these pamphlets with the outrage expressed in newspaper commentary suggests that division between "popular» and «elite» modes of discourse - the former broadly accepting of the punishment it so sensationally evoked, the latter an explicit repudiation of it - which cultural historians have identified throughout late eighteenth-century Europe ever since the pioneering work of Peter Burke ${ }^{43}$. And indeed, the repeated assertions of newspapers that these women were being burned alive, despite the fact that actual accounts of those executions published in those same paper clearly revealed otherwise, seems to suggest that few of their self-consciously «enlightened» or «sensitive» readers or writers were much to be found at execution days by the $1780 \mathrm{~s}^{44}$. On the other hand, as more recent historians have cautioned, it seems unlikely that any two such discourses were ever so purely antithetical in the minds of contemporaries in the way that such a categorisation would suggest, just as we know only too well how many members of the elite continued to attend Newgate executions ${ }^{45}$. Norbert Elias has asserted that «It is one of the peculiarities of Western society that, in the course of its development, th[e] contrast between the situation and code of conduct of the upper and lower strata has [in fact] decreased considerably.... [T] he sharp contrasts between the behaviour of different social groups. are steadily diminishing ${ }^{46}$. So it is by no means certain that we can exclusively link apparently elite or popular attitudes towards the burning of women with particular sectors of the populace simply because one or the other is almost exclusively associated with a particular genre.

Part of the solution to the seemingly intractable dilemmas surrounding the precise character(s) and role of opinion might be found in seeking other concrete evidence of changing attitudes regarding the appropriate means of punishing women in the public realm. Just such a measure may be found in the changing patterns of whipping in London during the late eighteenth century. For most of the second half of the eighteenth and much of the first quarter of the nineteenth centuries, the «bills of cravings» submitted by English sheriffs to the central government are preserved in the National Archives (formerly the Public Record office). As royally-appointed officials, the sheriffs were able to claim from the government a range of fees for tasks carried out during their year in office, including fixed amounts for their trouble in whipping convicted offenders. Systematic review of these records suggests much about the changing character and proportion of public, physical punishments in Hanoverian England, as the sheriffs were obliged to distinguish between the amount claimed for a «common» whipping and that claimed for a whipping «at the cart's tail» along a specified route ${ }^{47}$. These distinctions can be problematic in terms of evaluating the precise extent to which any particular whipping was carried out in a public setting. A «common» whipping might include not only one imposed in private but also (it seems likely) one carried out in the only semi-public setting of a fixed whipping post set in the enclosed yard outside the Sessions House in the Old Bailey. On the other hand, many claims for "public» whippings were made at the same level as those for whipping at the cart's tail, even though many such whippings - especially those carried out on Clerkenwell Green before the new Middlesex Sessions House from 1789 onwards - must have been markedly less "public» in character than a whipping through the streets, in 
which the punishment (as it were) was brought to the public rather than the public merely invited to attend the punishment ${ }^{48}$.

Table: Whipping in London, 1760-1809

\begin{tabular}{|l|l||c|c|c|}
\hline & & \multicolumn{2}{|c|}{ «Common» } & $\begin{array}{c}\text { At the Cart's Tail } \\
\text { (through the streets) }\end{array}$ \\
\hline & & Privately & At Post & \\
\hline The 1760s & $\mathrm{M}$ & 39 & {$[-]$} & 106 \\
\hline & $\mathrm{W}$ & 46 & {$[-]$} & 77 \\
\hline The 1770s 99 & $\mathrm{M}$ & 122 & {$[-]$} & 178 \\
\hline & $\mathrm{W}$ & 139 & {$[-]$} & 19 \\
\hline The 1780s & $\mathrm{M}$ & 570 & 16 & 275 \\
\hline & $\mathrm{W}$ & 370 & 2 & 19 \\
\hline The 1790s & $\mathrm{M}$ & 393 & 49 & 113 \\
\hline & $\mathrm{W}$ & 47 & 3 & 54 \\
\hline The 1800s & $\mathrm{M}$ & 471 & 28 & \\
\hline & & $\mathrm{W}$ & 85 & \\
\hline
\end{tabular}

Source: Sheriffs' Cravings, The National Archives (N.A.): E 197/34; T 64/262; T 90/165-950

Adjusting as best we can for these difficulties, the data suggest the swift and dramatic emergence of a near-total gender distinction in the application of a punishment whose experience must have been not only personally painful to its object, but humiliating and shameful in the extreme ${ }^{51}$. As late as the 1760 s, there was little discernible difference in the frequency with which men and women were whipped in London, either «commonly» or through the streets at the cart's tail. By the end of the following decade, the picture had already changed dramatically. During the 1770s men were now being whipped twice as often as women overall, and no less than nine times as often at the cart's tail. By September 1773, London's leading daily newspaper would approvingly quote one of its correspondents

who says he had the pain to see, as he was passing a certain street, an elderly woman severely whipp'd for a small offence, he shuddered at the sight, and with many others could not help execrating so preposterous a punishment on that sex, from whom he derived his being; a punishment which carries in the very face of it, so much indelicacy, inhumanity, and cruelty, as at once disgraces our laws and our nation, as a polite people ${ }^{52}$.

The decline was not entirely constant and consistent; during the severe criminal and penal crisis of the 1780s, whipping levels surged on both sides of the gender divide. Yet even so, the proportional distinction in whipping through the streets widened still 
further to a fourteen-fold level ${ }^{53}$. Where only twenty years earlier, men and women were equally likely to be seen whipped through the streets of the capital, men were now to be seen three times more often but women only a quarter as much. When Mary Siddon was convicted of non-capital stealing from a shop in June 1783, the presiding judge revealed a particular sensitivity to gender distinctions (at least in their public context) by specifically ordering that she should «be once severely and privately whipped, in the presence of females only», and then imprisoned at hard labour for six months $s^{54}$. Only one London woman was whipped at the cart's tail in 1786.

By the end of the eighteenth century, gender distinctions in whipping had become fundamental. Men were whipped ten times as often as women under any circumstances during the 1790s, and the whipping of a woman in public - either at the post or at the cart's tail - was almost entirely unknown. By the first decade of the nineteenth century, it had vanished completely, and the corporal whipping of women was altogether abolished in $1820^{55}$. Individual variations within the overall pattern of decline are again worth noting. In 1793 - the year after Mary Wollstonecroft's Vindication of the Rights of Woman, a direct challenge to the perception of women as principally domestic beings, was published to considerable furore - only two women were whipped in London, both outside the public eye. The year after that, no woman was whipped under any circumstances whatsoever. And in 1795 only one woman was whipped, privately: Bridget Greville, who, despite being a person of some substance, was convicted of stealing goods in a lodging house, a crime which must presumably have been deemed sufficiently egregious to merit unusual severity ${ }^{56}$.

21 So there is convincing corroborative evidence to suggest that evolving gender ideals informed dramatic changes in penal practices. There was also, moreover, a collapse in the placing of London women in the pillory which closely paralleled in timing and scale the decline of their public whipping ${ }^{57}$. Yet there was also one dramatic exception to this seemingly general picture of growing reluctance to subject the female body to public pain and indignity. Henrietta Radbourne may perhaps have been deliberately spared the indignity of burning at the stake in the Old Bailey; she was, however, hanged in a deliberately unusual manner for the time and place. In a procedure which seems to have echoed the old Tyburn ritual, she was rolled out of Newgate into Old Bailey in a cart, stopped between two posts, and hanged from a beam suspended between them. Then, under the terms of the Murder Act of 1752, and like as many as ten other women convicted of murder after her, her nude body was exposed and dissected before «a vast concourse of people» next door at Surgeon's Hall, a proceeding which was not abolished (for men and women alike) until $1832^{58}$. This seems at best a qualified triumph for the claims of male chivalry. If the definitive emergence of a belief in the superior sanctity of womanhood might generally be supposed to have resulted in some women gaining advantages at the hands of the English penal system in terms of the use of whipping and the pillory, as well as the abolition of burning (in fact, a measure which really only granted equality with men in being hanged), clearly there were still many who believed that female murderers should still be liable to the very worst punishment still prescribed by law.

Given all the apparent contradictions of the age regarding the sanctity of the female body, why then, with few or no expressions of either public satisfaction or dismay, was the burning of women definitively abolished in June 1790? A fuller answer can only be found by integrating the larger social and cultural assumptions explored in this first 
section with the personal and material dimensions of the question: the concerns of those officials physically closest to women condemned to be burned, the changing frequency of the practice, and its specific location in public space.

II suggests, in the first place, that we must adopt a more complicated perspective on the nature of public opinion and its interaction with officialdom than has generally been the case amongst historians of punishment. Broadly speaking, there have been essentially two views on this issue. The first, who might crudely be labelled «optimists», consist of those who view the emergence of new modes of rationality and/ or feeling as the driving forces behind demands for fewer capital offenses and the enhanced use of non-capital punishments, the latter of which were contrived to appeal to the condemned criminal's rational self-interest (by presenting him with a more certain punishment, and therefore one of more effective deterrent value to criminal and public alike) and to an increasingly «civilized», «enlightened» and/or «sensitive» polity. In this scheme of things, officialdom is a resistant force that is finally brought around to new views by either an increasing inability to deny the inefficacy of older penal practices or a genuine conversion to new ones in the face of the seemingly intractable problems of widespread criminality ${ }^{59}$. «Pessimists», in contrast, tend to follow Foucault in viewing the modernization of penal practices wrought by officialdom as - either intentionally or deliberately - a mask for darker, more sinister exercises of power under the superficially «enlightened» guise of less bloody and less public impositions on people convicted of criminal offenses. Such writers tend to view «crime» as itself an inherently problematic phenomenon, one more effectively defined by power differentials than by any intrinsic or widely-acknowledged standards of morality. Punishment therefore tends to be concerned first and foremost with the maintenance and policing of the boundaries of class difference, and officialdom to be both insensitive to the feelings of people outside its own realms of experience and largely unthinking in its responses to the driving imperative for maintaining divisions of power and the existing social order ${ }^{60}$

The abolition of 1790 does not clearly exemplify either version in any unproblematic way. In fact, its leading agitators were to be found in a small but crucially significant sector of officialdom: the sheriffs of London and Middlesex, the two men who were charged with actually carrying out all executions in the metropolis. The 1790 bill, introduced in the Commons only four days before the meeting of king and council that was expected to leave Sophia Girton to be burnt, was presented by Sir Benjamin Hammett, a former sheriff who, as he himself noted, had presided «at the melancholy occasion of seeing the dreadful sentence of the law put in execution» on Margaret Sullivan two years earlier ${ }^{61}$. It was chaired at the committee stage by Sir Watkin Lewes, who had been sheriff in 1772 when Elizabeth Herring was burnt at Tyburn for petty treason ${ }^{62}$. Finally, the concurrent petition for respite of Sophia Girton's execution was supported by yet another «one of the sheriffs» (either Thomas Baker or William Newman) ${ }^{63}$.

Most strikingly active of all sheriffs, past or present, was Matthew Bloxam. In office he had made a favorable impression in the press by his dedication to soliciting relief funds

Crime, Histoire \& Sociétés / Crime, History \& Societies, Vol. 9, n² | 2005 
and procedural justice for London debtors, as well as relief funds for poor convicts in Newgate ${ }^{64}$. He also gained favour by the courtesies he showed Sullivan in the days and hours leading up to her execution. In Bloxam's care, Sullivan seemed to take on an air more of tragically thwarted domestic womanhood than of a criminal deserving so shocking a fate. She was reported by one paper to have declined a gift of strawberries from Bloxam's wife, «intimating that the few remaining hours of life were too precious to be wasted in gratifying the palate» ${ }^{65}$. Two days later, it was reported that, in light of both Sullivan and her husband being executed the same day, Bloxam had «promised the mother he would take care of, and have [their daughter] properly educated; he has already taken the child, and will, no doubt, fulfill his promise in the utmost extent» ${ }^{66}$. And it was Bloxam who, a month later and in the face of initially strong reluctance on the part of government, pressed an ultimately successful case for Catherine Heywood's respite and pardon ${ }^{67}$.

Finally, four more late eighteenth-century metropolitan sheriffs did something else that would appear to be expressive of a growing, general disgust with the ritual of burning women. In claiming reimbursement for the additional costs attendant on the event («For faggots, brushwood \& shavings», «For post, chain \& tackle», for «Burying the bones»), the sheriffs who burned Isabella Condon in 1779 and Phoebe Harris in 1786 effectively doubled their claims by adding an additional charge (a further £6) for nothing other than "Attending» ${ }^{68}$. No sheriffs before them had claimed such a charge for such events, and in light of the standing expectation that all sheriffs should attend as a matter of course at all executions of sentences of law, it is difficult to read such an additional charge as anything except an explicit objection to this particular form of it. In short, it would not be too much to say that both the strongest expressions of dismay regarding the burning of women, as well as the most decisive political moves to abolish it, were made by neither statesmen nor by any «public opinion» soliciting their intervention, but rather by the sheriffs who were forced to attend executions as the most intimate of spectators. And perhaps this should not be surprising for, of all men of their status, they would have had both the most immediate and powerful sense of the physical horrors of the sentence and its actual impact on observers ${ }^{69}$. By comparison, as we have already seen, most newspaper correspondents did not usually express even enough knowledge of the event to understand that the woman was not actually burned alive. The sheriffs were familiar with the reality: one which, however mitigated in terms of the woman's personal suffering, was awful enough.

Nor were such reservations amongst sheriffs over the most gruesome chores entrusted to their office necessarily a development only of the 1780s. In October 1773 «Timothy Longstaff» wrote in to the Morning Chronicle to refute the criticisms of those who thought the sheriffs of that year negligent in failing to attend the last few executions at Tyburn (the most recent of which, interestingly, had been the burning of Elizabeth Herring for the murder of her husband). Public executions, he wrote, had «of late been one continued scene of riot, indecency, and drunkenness. I think [the sheriffs] cannot be said to have been at all wanting in their duty, and no man of the least feeling can condemn them for avoiding the most shocking scene that it is possible for man to be present at, and I think their non-attendance was a great proof of their humanity and sensibility $»^{70}$. This observation may have been meant as an ironic comment on the sheriffs' lack of fortitude; even so, it clearly admits the existence of understandable feelings of distaste and discomfort at the execution scene. Going back half a century more, to the last known instance of any condemned woman in England actually being 
burned alive - Catherine Hayes at Tyburn in 1726, for the murder of her husband - it is interesting to note that the executioner hired by the sheriffs to carry out the job failed to strangle her before the flames could reach her. In fact, her terrible death had been deliberately ordered by the secretary of state himself. "[T]he murder of John Hays», the Duke of Newcastle ordered the sheriffs, «appears to be aggravated by such Circumstances of Wickedness \& Barbarity, that in order to deter others from Offences of so heynous a Nature, it is His Majesty's Pleasure that the Sentence past upon Margaret [i.e., Catherine] Hays be put in execution with the utmost rigour, and in its full extent...» $\rangle^{71}$. In that case, the executioner's «failure» to strangle her must have the consequence of compassion exerted too late.

Clearly then qualms regarding the burning of women, at least in its «utmost rigour» and «full extent», need not be viewed solely as a product of any cultural superiority we might be inclined to ascribe solely to the presiding officials of the late, as opposed to the early, eighteenth century. At the same time, it may well be the case that the reservations of the sheriffs grew only the stronger as efforts to reduce the structured indiscipline of Tyburn from the 1730s onwards took hold ${ }^{72}$. As the distance between the condemned - and with them the presiding officials - and the crowd was widened in an effort to maximize the disciplinary effect of the execution ritual, so it must have been that those officials felt increasingly alone with, and less immune to, the physical and emotional sufferings of the former than they would have done in the midst of a more closely admitted, actively participatory crowd. We could even go so far as to speculate that the «festive» or "carnivalesque» temper of the early eighteenth-century Tyburn procession served (albeit, perhaps, unintentionally) to mask deeper disquiets on the part of all participants, just as the liquor served the condemned until the 1730 s was meant to fortify them for their coming ordeal.

So neither sensitivity to the suffering condemned nor the particular responsiveness to it of presiding officials need necessarily be read as uniquely characteristic of the late eighteenth century, though it may well be that new cultural discourses were giving greater public legitimacy to such feelings by that time ${ }^{73}$. This is not to reject a role for changing cultural values regarding femininity and punishment: indeed, that only three such executions in the late 1780 s could have the decisive impact they did speaks volumes for some kind of basic transformation in official and/or elite public sensibilities over the longer term, considering that far greater numbers of women had been burned at the stake in London only a century beforehand. Narcissus Luttrell's Brief Relation of life in London during the last two decades of the seventeenth century records no less than twelve (and perhaps as many as eighteen) such executions of women - all of them for coining - between 1683 and 1705, three of them on a single occasion in April $1687^{74}$. It is unclear from Luttrell how many of these women may have been afforded the mercy of being strangled prior to their immolation. Two women, burned in Smithfield on separate occasions in 1662 for having murdered their husbands, appear to have been denied that relative kindness ${ }^{75}$. A third, burnt as recently as 1678 for coining, was similarly left to die in the flames, "giving two or three lamentable Shrieks, [before] she was deprived both of Voice and Life, and so burnt to Ashes according to the Sentence ${ }^{76}$. It seems only to have been from the early 1690 s that executioners regularly enabled the condemned to strangle either before the fire was set or before the flames could reach her ${ }^{77}$. Small wonder, perhaps, that ten other Londoners condemned for coining at the end of 1696 refused to leave their prison cells on the morning of their execution «till such tyme as the Jaylor threatened to shoot 
them $»^{78}$. Perhaps the practice of strangulation had been inspired precisely by the sheer proliferation of such burnings alive during the Restoration era and a growing disgust they may have aroused ${ }^{79}$. It appears to have been sufficiently common by the mid-1720s that the secretary of state felt obliged to explicitly order its being omitted in the case of Catherine Hayes ${ }^{80}$. So relatively recent a shift might also explain why such later, liberalminded observers as Blackstone and Loughborough could so contentedly view such strangulation as a mercy to the weaker sex. The role of the sheriffs, then, suggests that, in thinking about the abolition of 1790, our explanations must be found, not so much in an authentic change in sensibilities, as in the changing physical organization of the execution scene over the long eighteenth century, changes which made it more and more difficult for those officials in particular to mask or deny their responses to the sufferings of the condemned.

A second material element must also be considered: the critical rise in the frequency with which women were burnt at the stake in London during the 1780s. Here we return to Loughborough's denial of the need for reform in 1786. In addition to the strangling which rendered the condemned insensible of any pain in burning, the Lord Chief Justice secondarily observed that «this sentence... was rarely inflicted,... so that burning for coining was not inflicted above once in half a century» ${ }^{81}$. Setting aside Loughborough's evident confusion on the matter (in fact, as the Appendix indicates, three women had been burnt for coining in London alone since 1750), the key factor here is how quickly and completely this confident prediction was refuted by subsequent experience. In fact, two more London women would be burned for coining within the next four years, two others would be condemned but ultimately spared it, and yet another would risk being burnt for murdering her mistress. Clearly, if infrequency of display (and hence, some would argue, the effectiveness of the deterrent) could constitute a case for preserving the option of burning women, the experience of the next few years wholly undermined Loughborough's position. Moreover, the particular severity of burning as a punishment for women may well have seemed the more striking in light of the relative infrequency with which women were ever executed at the Old Bailey for crimes other than murder ${ }^{82}$.

31 Consideration of the rapidly increasing frequency of such executions in London must therefore have tended dramatically to highlight the growing qualms in some sectors of opinion regarding the practice. In retrospect, it is remarkable that the strangling and burning of only three women within three years had the impact it did, given how many women more women a century earlier were being burned to death before strangulation was added to the practice ${ }^{83}$. The abolition of burning altogether, so easily shunted aside in 1786 , was fully conceded no later than May 1790 , when - despite having no legal obligation to do so - the Home Secretary recommended that Girton's execution be delayed until after the new bill had been enacted ${ }^{84}$. That this change came about so swiftly and irresistibly must principally be attributed to the widespread disgust it aroused, not in the public at large (now largely, as we have seen in our survey of newspapers, silent on the matter), but rather in the principal officials charged with carrying it out and in light of the far greater frequency with which the need to carry out such executions was arising. No sheriffs appear to have spoken for William Wilberforce's measure in 1786; when Hammett and several others led the charge four years later, the motion to introduce the bill was adopted unanimously by the Commons ${ }^{85}$. It was one thing for an MP, even one as well-connected with government 
as Wilberforce, to propose such a reform ${ }^{86}$. When the very men charged with putting it in force spoke, there could be little else to be said on the matter.

That said, there had also been a third change in the material circumstances surrounding the burning of women, one that is clearly important in helping to explain the particularly striking and rapid impact of the executions of Harris, Sullivan and Murphy: the abolition after November 1783 of Tyburn executions in favour of a more closely-staged hanging ritual immediately outside Newgate prison. This fundamental shift in the locale and the conduct of London executions was clearly intended to render the hanging of convicted felons more psychologically imposing than the procedure at Tyburn seemed to be by that time ${ }^{87}$. When it came to burning women convicted of treason, however, the change of venue posed a new and insurmountable problem, one which the detailed account of Margaret Sullivan's execution with which this article began ought all too vividly to convey. Burning at the stake simply was not susceptible of the kind of brief, shocking interposition on the normal urban setting which Newgate executions were clearly intended to achieve as part of their deterrent effect. The corpses of the hanged and the scaffolding on which they met their ends were routinely cut down and packed away within an hour or two, and with them must presumably have gone many of the reservations which increasingly sensitive onlookers might entertain regarding the morality of the punishment. But the prolonged strangulation of a woman, the time it took to reduce her body to ashes, and the physical scorching left in the wake of the process (not to mention the odour) - so much more powerfully redolent of both the pains of death and the doubts which such penal practices might arouse amongst more tender sensibilities - lingered far longer in the urban physical environment.

So it was that the burning of Phoebe Harris in May 1786 - the first such execution in the respectable, business-oriented neighbourhood of Newgate and the Old Bailey, rather than the semi-rural city boundary of Tyburn - attracted protest even a week before it took place, when The Times reported that «The inhabitants of the Old Bailey have sent a petition to the Lord Mayor, intreating that the unfortunate woman condemned to be burnt for coining may not suffer the sentence of the law opposite the debtors door at Newgate». That the neighbourhood's objections were not so much (or at all) with regard to the punishment itself, but rather simply its location, was confirmed by the same paper a month later: «When remission of burning was refused, the scene of inhumanity should have been changed; the consequences have been serious; several persons in the neighbourhood of Newgate lying ill, have been severely affected by the smoke which issued from the body of the unhappy female victim ${ }^{88}$. The "great nuisance» of burnings «to the neighbours» was again invoked by The Times in response to Sullivan's execution two years later ${ }^{89}$. And finally, it was in the face of another written objection from the local parishioners regarding «the great inconvenience and disorder which arise from the execution of the sentence of burning women... almost in the centre of the town", added to the opposition of one the sheriffs himself, that Sophia Girton's impending execution was repeatedly delayed until after the repealing law of June 1790 could be passed ${ }^{90}$. Thus, the burning of women only became definitively intolerable in the light of its now fully urbanized and inescapably public setting, as also by its unanticipated frequency and the particularly intense distaste it now aroused amongst those officials charged with carrying it out. 

legal reform, that a comprehensive account of penal reforms requires close attention to both macro- as well as microscopic levels of analysis. Once we descend from the relative heights of larger social and cultural explanations for events to the level of specific actors and circumstances, things may not appear to be as simple as we might think. New discourses regarding appropriate gender norms may well have been gaining ground by the late eighteenth century, but the balance of evidence for their «force» in the abolition of the burning of women was by no means uniformly felt or unproblematically realized. It was critically abetted by material circumstances that were unique to the British metropolis, specifically the combination of a wholly unexpected (though by no means wholly unprecedented) rise during the 1780s in the number of convictions of women for high treason in the form of coining, with the removal of executions from the periphery of the metropolis to its urban heart ${ }^{91}$. The recognition of new gender norms in penal practice was also critically abetted by a particular body of individuals: the sheriffs of London and Middlesex, not all of whom may have shared these new beliefs about how the greater tenderness of the female sex ought properly to be respected, but who were in any case much closer to the final scene than were those opponents of abolition - including men who advocated reform in other capital contexts - and thus less able comfortably to set aside the contradictory sensations which it aroused in (some of) them. We may in any case question how «chivalrous» that new culture was which soon seems to have forbade the public burning, or whipping, or pillorying, of women, but nonetheless still sanctioned the public dissection of their bodies when convicted of murder. Nor for that matter need we accord primacy of place to the role of other forces, like changing economic practices, urbanization and the consequent emergence within London of modernizing «spaces», outside of their highly particularized location in a constellation of actors and forces ${ }^{92}$. The same residents of the old Bailey and its parish who contributed so forcefully to the abolition of the burning of women had also petitioned against the removal there of executions in 1783 and, four decades later, would protest their continuing presence, with no apparent impact on either occasion, or any other of which we may lack record ${ }^{93}$. Where officialdom continued to believe the interposition of a dismaying public spectacle to be efficacious, they were more than willing to override the vociferous protests of urban inhabitants.

To conclude, then, the role of changing socio-cultural norms as forces in historical change must be neither denied nor undervalued, but we must distinguish these larger forces from more specific contexts and actors in explaining not only the nature of change but also its precise timing. A similar case regarding the interaction of social and cultural changes with circumstances could also be made (as I hope to do in the near future) regarding the declining use of capital punishment overall ${ }^{94}$. If changing sensibilities with regard to women and their bodies were all that counted in explaining the matter at hand, we must be somewhat puzzled as to how the abolition of the burning of women could be so easily rebuffed in 1786, largely ignored (apparently) for four more years, then finally unanimously endorsed by all members of the House of Commons. Such new attitudes may have been a necessary condition, but the unexpected degree of repetition in the display itself and its recently revised physical 
context were equally if not more crucial to the final decision. What, finally, I am arguing for - and what I have tried to provide an example of here - is a more complex and deeply-contextualized approach to the writing of penal history, one in which there is a closer attention to the respective roles and interactions between social and cultural developments on the one hand, with legal and administrative actors and imperatives on the other.

\section{BIBLIOGRAPHY}

\section{Archival Sources}

The National Archives of the United Kingdom [N.A.]:

E (Exchequer Papers)

HO (Home Office Papers)

PC (Privy Council Papers)

SP (Secretary of State Papers)

T (Treasury Board Papers)

\section{Contemporary Periodicals}

The Flying-Post; or the Post-Master.

The General Evening Post.

The Gazeteer.

The Gentleman's Magazine.

The London Chronicle.

The Morning Chronicle, and London Advertiser.

The Morning Herald \& English Chronicle.

The Morning Post.

Notes and Queries.

The Public Advertiser.

The St James' Chronicle.

The Times of London.

The Whitehall Evening Post. 


\section{Published \& Secondary Works}

Andrew, D.T. (Ed.), London Debating Societies 1776-1799, Chippenham, London Records Society, 1994.

Aspinall, A., Politics and the Press c.1780-1850, London, Home \& Van Thal, 1949.

Aspinall, A. (Ed.), The Later Correspondence of George III, 5 vols, Cambridge, Cambridge University

Press, 1962-1970.

Barker, H., Chalus, E. (Eds.), Gender in Eighteenth-Century England: Roles, Representations and Responsibilities, London, Longman, 1997.

Barker-Benfield, G.J., The Culture of Sensibility: Sex and Society in Eighteenth-Century Britain, Chicago: University of Chicago Press, 1992.

Beattie, J.M., Crime and the Courts in England 1660-1800, Princeton, Princeton University Press, 1986.

Beattie, J.M., Policing and Punishment in London 1660-1750: Urban Crime and the Limits of Terror, Oxford, Oxford University Press, 2001.

Bellamy, J., The Tudor Law of Treason: An Introduction, London, Routledge \& Kegan Paul, 1979.

Blackstone, W., Commentaries on the Laws of England (9th edn, 1783), Ed. Morrison, W., 4 vols, London, Cavendish, 2001.

Burke, P., Popular Culture in Early Modern Europe, London, Maurice Temple Smith, 1978.

Campbell, R., Sentence of Death by Burning for Women, Journal of Legal History, 1984, V, pp. 44-59.

Cockburn, J.S., Patterns of Violence in English Society: Homicide in Kent, 1560-1985, Past \&

Present, February 1991, CXXX, pp. 99-100.

Commons Journals.

The Confession and Execution... of the several Prisoners that suffered at Tyburn on Wednesday the 17th of April..., London, 1678.

Davidoff, L., Hall, C., Family Fortunes: Men and Women of the English Middle Class 1780-1850, London, Hutchinson, 1987.

Devereaux, S., The Making of the Penitentiary Act, 1775-1779, The Historical Journal, 1999, XLII, pp. 405-433.

Devereaux, S., Criminal Justice and English Governance 1750-1810: Convicts and the State, Basingstoke, Palgrave, forthcoming 2006.

Devereaux, S., «Recasting the Theatre of Execution in London: The Abolition of Tyburn» (forthcoming).

Elias, N., The Civilizing Process (revised edn), Trans. Jephcott, E., Eds. Dunning, E., Goudsblom, J., Mennell, S., Oxford, Blackwell, 2000.

Exwood, M., Lehmann, H.L. (Eds.), The Journal of William Schellinks' Travels in England 1661-1663 (Camden Society, 5th Series, I); London, Royal Historical Society, 1993.

Foucault, M., Discipline and Punish: The Birth of the Prison, Trans. Sheridan, A., London, Allen Lane, 1977.

Gaskill, M., Crimes and Mentalities in Early Modern England, Cambridge, Cambridge University Press, 2000. 
Gatrell, V.A.C., Crime, Authority and the Policeman-State, in Thompson, F.M.L. (Ed.), The Cambridge Social History of Britain 1750-1950 - Volume Three: Social Agencies and Institutions, Cambridge, Cambridge University Press, 1990, pp. 243-310.

Gatrell, V.A.C., The Hanging Tree: Execution and the English People 1770-1868, Oxford, Oxford University Press, 1994.

Gavigan, S.A.M., Petit Treason in Eighteenth Century England: Women's Inequality Before the Law, Canadian Journal of Women and the Law, 1989-90, III, pp. 335-374.

The Groans of Newgate, Sorrowful Lamentation, and Last Farewell to the World, of the Unfortunate Malefactors, Who are to be Executed on Wednesday next, upon a Scaffold erected at the Debtors Door, Newgate. Also, the sorrowful Lamentation of Phoebe Harris, who is on the same Day to be burnt at a Stake for Coining [London, 1786], (Guildhall Library, B'side 22.115).

Hale, M., Pleas of the Crown: or, A Methodical Summary of the Principal Matters relating to that Subject, London, 1678.

Hall, C., The Early Formation of Victorian Domestic Ideology, in Burman, S. (Ed.), Fit Work for Women, London, Croom Helm, 1979, pp. 15-32.

Harris, T., Problematising Popular Culture, in Harris, T. (Ed.), Popular Culture in England c. 1500-1850, Basingstoke, Macmillan, 1995, pp. 1-27.

Harvey, A.D., Burning Women at the Stake in Eighteenth-Century England, Criminal Justice History, 1990, XI, pp. 193-195.

Heath, J., Eighteenth Century Penal Theory, Oxford, Clarendon Press, 1963.

Historical Manuscripts Commission [H.M.C.], [Series 30] Manuscripts of J.B. Fortescue Preserved at Dropmore, 10 vols, London, HMSO, 1892-1927.

Ignatieff, M., A Just Measure of Pain: The Penitentiary in the Industrial Revolution 1750-1850, New York, Pantheon Books, 1978.

Kent, S.K., Gender and Power in Britain 1640-1990, London, Routledge, 1999.

Kerr, R.J and Duncan, I.C. (Eds.), The Portledge Papers,... from December 10th 1687 - August 7th 1697, London, Jonathan Cape, 1928.

Langford, P., A Polite and Commercial People: England 1727-1783, Oxford, Clarendon Press, 1989.

Laqueur, T.W., Crowds, Carnival and the State in English Executions 1604-1868, in Beier, A.L. et al. (Eds.), The First Modern Society: Essays in English History in Honour of Lawrence Stone, Cambridge, Cambridge University Press, 1989, pp. 305-355.

The Last Dying Speeches, Confession, and Execution of John Stokes, Isaac Davis, and Mary Williamson,..., London, 1684.

The Last Speech, Confession \& Prayer of Joyce Ebbs... As also,... her heavie groans and shrieks in the fire, and the providing of half a sheet spread over with pitch, to shorten the time of her miserable torment, London, 1662.

The Laws Respecting Women, as They Regard their Natural Rights, or Their Connections and Conduct, London, 1777; Reprint Edn, Dobbs Ferry, NY, Oceana, 1974.

Lieberman, D., The Province of Legislation Determined: Legal Theory in Eighteenth-Century Britain, Cambridge, Cambridge University Press, 1989. 
Linebaugh, P., The London Hanged: Crime and Civil Society in the Eighteenth Century, Harmondsworth, Allen Lane/The Penguin Press, 1991.

The Life and Death of Christian Bowman, alias Murphy; Who was burnt at a Stake, in the Old Bailey, on Wednesday the 18th of March 1789, for High Treason, in feloniously and traitorously counterfeiting the Coin of the Realm. Containing her Birth and Parentage, youthful Adventures, Love Amours, fatal Marriage, unhappy Connections, and untimely Death [London,1789], (British Library, 1077.g.36(28)).

Luttrell, N., A Brief Historical Relation of State Affairs from September 1678 to April 1714, 6 vols, Oxford, Oxford University Press, 1857.

McGowen, R., A Powerful Sympathy: Terror, the Prison, and Humanitarian Reform in Early Nineteenth-Century Britain, Journal of British Studies, 1986, XXV, pp. 312-334.

McGowen, R., The Body and Punishment in Eighteenth-Century England, Journal of Modern History, 1987, LIX pp. 651-679.

McGowen, R., The Changing Face of God's Justice: The Debate over Divine and Human Punishment in Eighteenth-Century England, Criminal Justice History, 1988, IX, pp. 63-98.

McGowen, R., Revisiting The Hanging Tree: Gatrell on Emotion and History, British Journal of Criminology, 2000, XL, pp. 1-13.

McKenzie, A., Martyrs in Low Life? Dying 'Game' in Augustian England, Journal of British Studies, 2003, XLII, pp. 167-204.

McKenzie, A., Tyburn's Martyrs: Execution in England 1670-1770, London, Hambledon, forthcoming 2006.

Mather, I., The Wonders of Free Grace (1691).

Mendelson, S., Crawford, P., Women in Early Modern England 1550-1720, Oxford, Clarendon Press, 1998.

Namier, L., Brooke, J. (Eds.), The History of Parliament: The House of Commons 1754-1790, 3 vols, London, Secker \& Warburg, 1964.

Ogburn, M., Spaces of Modernity: London's Geographies 1680-1780, New York, The Guilford Press, 1998.

The Parliamentary History of England, from the Earliest Period to the Year 1803, Ed. Cobbett, W., 36 vols, London, 1806-1820.

The Parliamentary Register; or, History of the Proceedings and Debates of the House of Commons and the House of Lords, Ed. Debrett, J., 45 vols, London, 1780-1796.

Price, R., British Society 1680-1880: Dynamism, Containment and Change, Cambridge, Cambridge University Press, 1999.

Radzinowicz, L., A History of English Criminal Law and Its Administration from 1750 - Volume One: The Movement for Reform, London, Stevens \& Sons, 1948.

Reed, M., The Transformation or Urban Space 1700-1840, in Clark, P. (Ed.), The Cambridge Urban History of Britain - Volume Two: 1540-1840, Cambridge, Cambridge University Press, 2000, pp. 615-640.

Richardson, R., Death, Dissection and the Destitute (second edn), London, Phoenix Press, 2001. Shoemaker, R.B., Gender in English Society 1650-1850: The Emergence of Separate Spheres?, London, Longman, 1998. 
Shoemaker, R.B, Streets of Shame: The Crowd and Public Punishments in London, 1700-1820, in Devereaux, S., Griffiths, P. (Eds.), Essays in Penal Politics and Culture 1500-1900: Punishing the English, Basingstoke, Palgrave, 2004, pp. 232-257.

Smith, G.T., The State and the Culture of Violence in London 1760-1840, PhD thesis, University of Toronto, 1999.

Spierenburg, P., The Spectacle of Suffering: Executions and the Evolution of Repression: From a Preindustrial Metropolis to the European Experience, Cambridge, Cambridge University Press, 1984.

Spierenburg, P., The Body and the State: Early Modern Europe, in Morris, N., Rothman, D.J. (Eds.), The Oxford History of the Prison: The Practice of Punishment in Western Society, New York, Oxford University Press, 1995, pp. 49-77.

Spierenburg, P., Four Centuries of Prison History: Punishment, Suffering, the Body, and Power, in Finzsch, N., Jütte, R. (Eds.), Institutions of Confinement: Hospitals, Asylums, and Prisons in Western Europe and North America 1500-1950, New York, German Historical Institute/Cambridge University Press, 1996, pp. 17-35.

Styles, J., 'Our Traiterous Money Makers': The Yorkshire Coiners and the Law 1760-83, in Brewer, J., Styles, J. (Eds.), An Ungovernable People: The English and their Law in the Seventeenth and Eighteenth Centuries, London, Hutchinson, 1980, pp. 172-249.

A True Narrative of the Confession and Execution... at Tyburn On Wednesday the 5th of this Instant February..., London, 1684.

The True Narrative of the Confession and Execution of Elizabeth Hare..., London, 1683.

The True and Remarkable Lives and Adventures of David Clarey, under Sentence of Death in Newgate, for Setting Fire to his House. And Catherine Heyland, condemned to be burnt at a Stake, for Coining [London, 1790] (Cambridge University Library, 2708 50.d.3).

Vickery, A., Golden Age to Separate Spheres? A Review of the Chronology of English Women's History, The Historical Journal, 1993, XXXVI, pp. 383-414.

A Warning for Bad Wives: or, The Manner of the Burning of Sarah Elston, London, 1678.

The Whole Proceedings on the King's Commission of the Peace, Oyer and Terminer, and Gaol-Delivery for the City of London; and also the Gaol-Delivery for the County of Middlesex; Held at Justice-Hall in the Old Bailey... [OBSP].

see http://www.oldbaileyonline.org/

Wilf, S., Imagining Justice: Aesthetics and Public Executions in Late Eighteenth-Century England, Yale Journal of Law and the Humanities, 1993, V, pp. 51-78.

\section{APPENDIXES}

Women Convicted of High and Petty Treason at the Old Bailey, 1750-1790

\begin{tabular}{|l|l|l|l|}
\hline Conviction & Name & Crime & Final Disposition \\
\hline Jan 1758 & Alice Davis & HT - Coining & Strangled \& burnt at Tyburn, 31 March 1758 \\
\hline Jan 1758 & Margaret Larney & HT - Coining & Strangled \& burnt at Tyburn, 2 Oct 1758 \\
\hline
\end{tabular}




\begin{tabular}{|c|c|c|c|}
\hline Sept 1773 & Elizabeth Herring & $\begin{array}{l}\text { PT - Murder of } \\
\text { Husband }\end{array}$ & Strangled \& burnt at Tyburn, 13 Sept 1773 \\
\hline Dec 1776 & Elizabeth Parker & HT - Coining & Respited 14 April 1777, \& pardoned 1 Aug 1777 \\
\hline Sept 1779 & Isabella Condon & HT - Coining & Strangled \& burnt at Tyburn, 27 Oct 1779 \\
\hline Jan 1780 & Mary Williams & HT - Coining & Respited 5 April 1780 \& pardoned 30 April 1781 \\
\hline April 1786 & Phoebe Harris & HT - Coining & Strangled \& burnt at Newgate, 21 June 1786 \\
\hline July 1787 & $\begin{array}{l}\text { Henrietta } \\
\text { Radburne }\end{array}$ & $\begin{array}{l}\text { PT - Murder of } \\
\text { Mistress }\end{array}$ & $\begin{array}{l}\text { Conviction revised; hanged on special gallows } \\
\text { at Newgate, } 14 \mathrm{Dec} 1787\end{array}$ \\
\hline April 1788 & Catherine Heyland & HT - Coining & $\begin{array}{l}\text { Pardoned on condition of transportation for } \\
\text { life to New South Wales, } 17 \text { April } 1789\end{array}$ \\
\hline May 1788 & Margaret Sullivan & HT - Coining & Strangled \& burnt at Newgate, 25 June 1788 \\
\hline Sept 1788 & $\begin{array}{l}\text { Christian Murphy } \\
\text { als Bowman }\end{array}$ & HT - Coining & Strangled \& burnt at Newgate, 18 March 1789 \\
\hline April 1790 & Sophia Girton & HT - Coining & $\begin{array}{l}\text { Pardoned on condition of transportation for } \\
\text { life to New South Wales, } 12 \text { June } 1790\end{array}$ \\
\hline
\end{tabular}

Sources:The Times; Morning Chronicle; OBSP; and the National Archives (SP 44/94, pp. 55,76,162-164; SP 44/95, p. 112; HO 13/6, pp. 425-428; HO 13/7, p. 490; T 64/262).

\section{NOTES}

1. Research for this paper was completed during my tenure of a Faculty Research Fellowship in the Centre for Critical and Cultural Studies at the University of Queensland, and I am grateful to Professor Graeme Turner and the staff and fellows of the Centre for their interest in and support of my work. Earlier versions of it have been presented to various gatherings in Brisbane: the Staff-Student Seminar Series at Griffith University; the seminar series of the Centre for the History of European Discourses at the University of Queensland; the Fourteenth Biennial Conference of the Australasian Association for European History; and the Twenty-Second Annual Conference of the Australia and New Zealand Law and History Society. I am grateful for the many helpful comments and suggestions I received on all those occasions. I owe thanks as well to Donna Andrew, John Beattie, Paul Crook, Randall McGowen, Andrea McKenzie, Elizabeth Roberts and two anonymous reviewers for reading the first draft and helping me to refine and (I hope) improve the arguments.

2. Morning Chronicle (26 June 1788). For the silence in most newspapers as to the details of executions, see Gatrell (1994, p. 55).

3. The most comprehensive account of the substance and ultimate repeal of «the bloody code» remains Radzinowicz (1948).

4. Devereaux (forthcoming 2006), ch 4. 
5. Radzinowicz (1948, ch 6). The rowdiness of the crowd at executions was little changed, however (ibid., pp. 204-205), for which see also Laqueur (1989).

6. Foucault (1977); Wilf (1993).

7. Morning Chronicle (26 June 1788).

8. Notes and Queries (1850, 1st ser., II, p. 165).

9. The Times (24 June 1788; emphases in original).

10. Gentleman's Magazine (1788, LVIII, p. 652).

11. Radzinowicz (1948, pp. 209-213, 476-479); Campbell (1984); Gavigan (1989-1990); Harvey (1990).

12. Gatrell (1994, p. 25).

13. See the references at notes 58-9 below and the brief discussion in the main text there.

14. Blackstone (1783, IV, pp. 70-71); Radzinowicz (1948, pp. 652-654); Styles (1980, pp. 177, 182).

15. Hale (1678, pp. 24-25); Blackstone (1783, IV, p. 160).

16. Laws Respecting Women (1777, p. 344).

17. Gatrell (1994, p. 337).

18. Heath (1963, pp. 178-184); Lieberman (1989, pp. 208-209); Devereaux (1999).

19. Blackstone (1783, IV, p. 73).

20. Davidoff and Hall (1987, pt I).

21. For that subject in particular, see Hall (1979).

22. Barker-Benfield (1992, esp. ch 5).

23. Vickery (1993); Barker and Chalus (1997); Shoemaker (1998); Kent (1999, ch. 5-7); Price (1999, pp. 205-226).

24. Loughborough, the former Alexander Wedderburn, had as attorney general been a close ally of Eden and Blackstone in advocating the wider substitution of imprisonment for transportation during the late 1770s. His personal desire to see a greater restriction on the exercise of the capital code was thought by some to be a key factor in the dramatic reduction in hanging levels in London during the 1790s (Gatrell [1994, p. 21 n48]).

25. Parliamentary History (1806-1820, XXVI, p. 199).

26. The Times (24 June 1788; 27 June 1788; 30 June 1788).

27. Note that here the point is driven home the more forcefully by use of the past tense; even the Irish, The Times implies, have now abandoned even «the appearance» of this ancient «barbarism». 28. For an excellent summary of the cultural context prior to the period covered by this article, see Mendelson, Crawford (1998, ch 1).

29. Morning Chronicle (28 Oct 1779; 29 Nov 1782).

30. Andrew (1994, p. 93).

31. The Times (23 June 1786; emphasis in original).

32. OBSP (1786-1787, p. 764; 1787-1788, pp. 2-4).

33. OBSP (1787-1788, pp. 421-425, 431); Aspinall (1962-1970, I, pp. 383-384); Radzinowicz (1948, pp. 209-213, 652-653); Beattie (1986, pp. 141-146, 451-453).

34. Murphy's execution does, however, seem to have provoked a debate two weeks later at the Westminster Forum on the proposition that «Is not that Law Cruel and Unjust which inflicts the Punishment of Burning alive upon a Woman for the same Offence which subjects a Man only to the usual Forms of Execution?» (Andrew [1994, p. 254]). But note, again, both the incorrect understanding of the punishment («Burning alive») and the focus on simple gender disproportion in the punishment rather than the supposed sanctity of the female body.

35. Of the two leading London dailies, the Morning Chronicle and The Times of London, only the latter is extant for the years 1789-1790, but a similar silence on the subject prevails in the pages of The Gazetteer, the General Evening Post, the London Chronicle, the Morning Post, the Public Advertiser, the St James' Chronicle, and the Whitehall Evening Post. 
36. The obvious contrast here is with the persistence of later efforts to repeal elements of the capital code before the first major repeals of the 1820s. Various bills abolishing capital punishment for specific offenses were repeatedly passed by the Commons, only to be overturned by a House of Lords that followed the opposition of the judges. See Radzinowicz (1948, part V).

37. For example, the same indignant text quoted from The Times (above at note 32) appeared verbatim in The Whitehall Evening-Post (22-24 June 1786) and the Morning Herald \& English Chronicle (s.d.).

38. Aspinall (1949, p. 69).

39. For a recent discussion of the "popular» literature of crime and punishment, see Gatrell (1994, ch. 4-5).

40. Groans of Newgate... [1786].

41. True and Remarkable... [1790].

42. The Life and Death of Christian Bowman, alias Murphy [1789].

43. Burke (1978, esp. pp. 270-281).

44. It was presumably out of this sort of conviction - that no «respectable» person would be seen at so degrading an event as a public hanging - that the Morning Chronicle assured its readers early in 1791 that the recently deceased George Selwyn, notorious amongst contemporaries and antiquarians alike for his frequent attendance at executions, that he had confessed to his friends that he had in fact only ever been to one in his entire life (28 Jan. 1791; 18 Feb. 1791).

45. Gatrell (1994, part III); Harris (1995).

46. Elias (2000, p. 383).

47. Until 1779 the sheriffs could claim $£ 1$ for each «common» whipping and $£ 2$ for each whipping at the cart's tail; afterwards, the amounts were tripled to $£ 3$ and $£ 6$ respectively.

48. For the perhaps increasingly stationary character of public whippings in late eighteenthcentury London, see Shoemaker (2004, pp. 232-257).

49. The London and Middlesex sheriffs' cravings for the year 1773 is missing.

50. My count in this table follows the sheriffs' cravings in treating the "year» as the shrieval year, that is running from October of one year to September of the next. Thus «1786» for the purposes of this table would be October 1785 through September 1786.

51. Indeed, some senior officials clearly thought that whipping any person, male or female, was not a step lightly to be undertaken. When an old Bailey jury of June 1783 recommended that William Jenkins be «whipped throughout Knightsbridge» for stealing twenty-nine rabbits, the presiding judge Edward Willes demurred: «I have a great objection to a public whipping, unless a man has lost his character; it is taking away his bread for life; unless a man is quite abandoned, I never give him a public whipping; let him be privately whipped twice with severity and discharged» (OBSP [1782-1783, p. 529]).

52. Morning Chronicle (29 Sept. 1773).

53. The 1780 s was an era of intense crisis in terms of both soaring levels of convicted criminality and a severely-limited capacity to punish convicted criminals appropriately in the prolonged absence (from 1775 to 1787) of the most widely-accepted mode of punishment next to capital punishment, transportation to the British colonies. I suspect that the intense surge in levels of whipping reflected a deep dissatisfaction, especially amongst London officials, with imprisonment as an alternative to transportation; many whipping sentences in London were, indeed, imposed in conjunction with sentences of imprisonment (see Devereaux [forthcoming 2006, part II]).

54. OBSP (1782-1783, p. 532). Siddon had stolen goods valued at only $3 \mathrm{~s} 6 \mathrm{~d}$; the value had to be $5 \mathrm{~s}$ or more to be a hanging offence (Beattie [1986, pp. 178-179]).

55. 1 Geo. IV, c57. See the discussion in Smith (1999, pp. 395-399).

56. OBSP (1794-1795, pp. 1183-1185). 
57. Women were pilloried in London one-third as often as men during the 1760s, only one-fifth as often during the following three decades, and not at all by the turn of the nineteenth century (source: Sheriffs' Cravings, as in Whipping Table above).

58. The Times (15 Dec. 1787; 18 Dec. 1787). The latter reports that Radbourne's dissection was rendered especially alarming and ludicrous by the sudden collapse of a skeleton from one of the niches surrounding the room. Public dissection of the corpses of all convicted murders had been prescribed by the «Murder Act» of 1752 (25 Geo. II, c37, s2) and was abolished eighty years later by the $2 \& 3$ Will. IV, c75, s16. For an extended analysis of these measures and their wider contexts, see Richardson (2001). For a brief reflection on public dissection's horrors and potential titillations, see Gatrell (1994, pp. 264-266).

59. In this camp might be located the work of Radzinowicz (1948), Spierenburg $(1984,1995,1996$, drawing substantially on the insights and argumentative structures of Elias [2000]), Beattie (1986, ch. 9-10; 2001, pt II), and McGowen (1986, 1987, 1988, 2000).

60. On this side would be located Ignatieff (1978), Linebaugh (1991), Gatrell (1990; 1994).

61. Parliamentary History (1806-20, XXVIII, p. 782); Namier and Brooke (1964, II, p. 575). The most detailed account I have found of Hammett's introduction of the bill (London Chronicle [8-11 May 1790]) emphasizes the gender inequality inherent in the punishment (as noted above) and sounds a note of legal circumspection - rather than chivalrous outrage - in asserting that «the Sheriff who did not execute the sentence of burning alive was liable to a prosecution; but he thanked God that there was not an Englishman to be found whose humanity did not triumph over the severity of the sentence, and who did not choose to run the risk rather than attend to the letter of the judgment».

62. Commons Journals (XLV, p. 498); Namier and Brooke (1964, III, p. 40).

63. H.M.C. (1892-1927, I, p. 586).

64. Namier and Brooke (1964, II, p. 99); Morning Chronicle (30 Oct. 1787; 17 March 1788; 23 June 1788; 10 June 1788; 2 Aug. 1788; 29 Sept. 1788).

65. The Times (26 June 1788).

66. Morning Chronicle (28 June 1788).

67. N.A., HO 13/6, pp. 237-238; Aspinall (1962-1970, I, pp. 383-384).

68. Sheriffs' Cravings (N.A., T 64/272). And again, it is striking that this practice more or less corresponds with the decline from the 1770s onwards in the use of whipping at the cart's tail or of the pillory against convicted London females. One newspaper of 1790 mistakenly believed that the award of these charges in fact inspired resistance amongst executioners to the abolition of burning (Public Advertiser [15 May 1790]).

69. Biographical information on the sheriffs (noted above) is thin on the ground, but all appear to have shared a parvenu status by comparison with more prominent members of parliament. This would certainly be congruent with the contention of Norbert Elias and others that more tender sensibilities were to be found first amongst the bourgeoisie. However, as I hope this part of the discussion makes clear, it is not at all apparent that we need necessarily have reference to social standing in explaining the growth in shrieval objections to the burning of women.

70. Morning Chronicle (14 Sept. 1773; 9 Oct. 1773 [quote]). This presumably explains why, in the Sheriffs Cravings for that year, no claim was made for Herring's execution (N.A., T 64/262).

71. N.A., SP 44/124, p. 284.

72. Wilf (1993, pp. 55-63); McKenzie (2003, p. 197 n139); McKenzie (2004).

73. Langford (1989, ch. 10); Barker-Benfield (1992).

74. Luttrell (1857, passim [I, p. 400 for the triple event of April 1687]). For the social, economic and cultural contexts of coining during this era, see Gaskill (2000, ch. 4-5).

75. Last Speech (1662); Exwood and Lehman (1993, p. 86).

76. Warning for Bad Wives (1678, p. 7). 
77. Confession and Execution (1678); True Narrative (1683); True Narrative (1684); Last Dying Speeches (1684); Mather (1691, pp. 168-169); The Flying-Post; or the Post-Master (1-3 June 1699).

78. Kerr and Duncan (1928, p. 247).

79. The coincidence of the emergence of the practice with the Glorious Revolution of 1688-9 may be suggestive. Perhaps it was intended to highlight the superior virtues of the new, Protestant regime by comparison with the bloodthirsty tyranny of its Catholic predecessor.

80. Equally strikingly, and to move backwards yet further chronologically, the authoritative history of treason during the Tudor era finds that «There may not, in fact, in the period... have been a single instance when a woman was burned for high treason» and only two known instances of women being burned for petty treason (Bellamy [1979, p. 207]).

81. Parliamentary History (1806-20, XXVI, p. 199).

82. Contemporary figures for condemnation and execution at the Old Bailey do not distinguish gender, but my own calculations suggest that, no later than the 1760s, only one or two women were hanged in any given year, and it was not uncommon for entire years to go by without a single execution of a female.

83. There can be little doubt that the need for abolition was felt most powerfully in the light of the capital's experience of this punishment. Before the advent of the railways from the 1840s, it is unlikely that many people outside London were able to attend any other executions than those held twice-yearly for their respective counties. And even Kent, one of the most populous counties in England, seems to have had only two occasions to burn women at the stake after 1755, and only three times more during the entire two centuries beforehand (Cockburn [1991, pp. 99-100]).

84. H.M.C. (1892-1927, I, p. 586).

85. Parliamentary Register (1780-96, XXVII, p. 579).

86. The interest of Pitt's government in Wilberforce's measure is apparent in the support it attracted from Pitt himself and the Attorney General in the Commons, as well as the Home Secretary in the House of Lords (Morning Chronicle [17 May 1786; 24 June 1786; 6 July 1786]). The motives for that support are explored in Devereaux (forthcoming 2006, ch 4).

87. Wilf (1993); Devereaux (forthcoming).

88. The Times (15 May 1786; 23 June 1786).

89. The Times (26 June 1788).

90. H.M.C. (1892-1927, I, p. 586; for the quote); N.A., HO 13/7, p. 470, 475, 478, 482, 485 (for the respites).

91. I am as yet unable to explain the underlying causes of this surge, nor to determine whether it was the result of either a new burst of prosecutorial energy on the part of government with regard to coining or of some procedural change which made convictions more likely.

92. Ogburn (1998); Smith (1999, pp. 359-366); Reed (2000).

93. Gentleman's Magazine (1783, LIII, p. 1061; The Gazeteer (10 Dec 1783); «Petition of the undersigned Housekeepers and Inhabitants of London \& its Vicinity», 1 Dec 1820 (N.A., PC 1/68/ Dec. 1820).

94. For a broad-brush argument to this effect, see Gatrell (1994, pp. 1-25). 


\section{ABSTRACTS}

In June 1790 the British parliament abolished one of the most striking and horrific modes of capital punishment still practised in England, the burning at the stake of women convicted of treason. Previous accounts of this change have generally regarded it as a long overdue measure in a society that was increasingly characterized by enlightened, civilized values, to say nothing of a growing idealization of women. This paper argues that the explanation is more complicated and ambiguous. Although changing social and cultural factors were vital, a full explanation requires close attention to the particular people and the material circumstances involved.

En juin 1790, le parlement britannique abolit l'une des modalités de la peine capitale parmi les plus frappantes et horribles de celles encore pratiquées en Angleterre: la condamnation au bûcher des femmes accusées de trahison. Les analyses antérieures de ce changement l'ont généralement considérée comme une mesure depuis longtemps obsolète, dans une société qui se caractérisait de plus en plus par les valeurs civilisées des Lumières, sans même parler de l'idéalisation croissante de la femme. Cet article présente une explication plus complexe et plus ambiguë. En dépit du caractère crucial des changements sociaux et culturels, il faut en effet porter une attention particulière aux personnes et aux circonstances matérielles en cause.

\section{AUTHOR}

\section{SIMON DEVEREAUX}

Department of History, University of Victoria, P.O. Box 3045, Victoria, B.C., V8W 3P4, Canada, devereaux@uvic.ca

Simon Devereaux is an Assistant Professor at the Department of History, University of Victoria (B.C., Canada). He has previously published: The Fall of the Sessions Paper: The Criminal Trial and the Popular Press in Late Eighteenth-Century London, Criminal Justice History, 2003, XVIII, pp. 57-88. He has also co-edited (with A.N May. and G.T Smith)., Criminal Justice in the Old World and the New: Essays in Honour of J.M. Beattie, Toronto, Centre of Criminology, 1998; and (with P. Griffiths) Punishing the English: Essays in Penal Politics and Culture 1500-1900, Basingstoke, Palgrave, 2004. He is currently researching Criminal justice and the state in Hanoverian England. 